\title{
The Effect of Sport Tourism Management on Support for Tourism Development
}

\author{
Ra'ed Masa'deh ${ }^{1}$, Mohammed Abdullah Nasseef ${ }^{2}$, Hamzeh Alshayeb $^{3}$, Jawad Ojilat ${ }^{3} \&$ Malek Alshafiee $^{3}$ \\ ${ }^{1}$ Management Information Systems Department, School of Business, The University of Jordan, Amman, Jordan \\ 2 Department of Business Administration, Faculty of Economics and Administration, King Abdulaziz University, \\ Jeddah, Saudi Arabia \\ ${ }^{3}$ Faculty of Tourism and Hospitality Management, The University of Jordan, Aqaba, Jordan \\ Correspondence: Ra'ed Masa'deh, Management Information Systems Department, School of Business, The \\ University of Jordan, Amman, Jordan. Tel: 962-3-209-0450. E-mail: r.masadeh@ju.edu.jo
}

Received: June 6, 2017

doi:10.5430/jms.v8n3p20
Accepted: June 20, 2017

Online Published: June 27, 2017

URL: https://doi.org/10.5430/jms.v8n3p20

\begin{abstract}
This study aims to examine the impact of sport tourism (by using the variables of social impacts, environmental impacts, and economic impacts) on support for tourism development. A total of 480 questionnaire containing 19 items was used to collect information from the local residents in Aqaba city. Multiple regression analysis was conducted to test the research hypotheses. Results of the current study revealed that there are significant impacts of two independent variables (i.e. environmental impacts, and economic impacts) on support for tourism development; whereas the vriable of social impacts has not significant impact on it. Results of T-test showed that there is no significant difference in the impact of resident attitudes towards sustainable tourism development in favor of gender. On the other hand, results of ANOVA test found that while there is no significant difference in the impact of resident attitudes towards sustainable tourism development that can be attributed to age and educational level; a significant difference in favor of personal income was found.
\end{abstract}

Keywords: sport tourism, tourism development, Aqaba, Jordan

\section{Introduction}

Tourism industry has started to recognize sport tourism, i.e. the experience of travel to engage in or view sport-related activities as an important market. In order to compete in the growing sport tourism market, it is crucial for communities to develop a profound understanding of the benefits and impacts of sport tourism, of the process of bidding for events, possible sponsorship opportunities and other elements involved in the planning and hosting of a successful sport event. Sport tourism refers to the experience of travel to engage in or view sport-related activities. It is generally recognized that there are three types of sport tourism: Sport event tourism, active sport tourism, and nostalgia sport tourism. Sports event tourism includes hallmark events such as the Olympic Games and the World Cup, football is part of this type of sport tourism. Nostalgia sport tourism involves traveling to famous sport-related attractions. Visits to various Sporting hall of fames such as the Women's College Basketball Hall of Fame in Knoxville, Tennessee and the Baseball Hall of Fame in Cooperstown, New York are good examples of theseSport-related establishments (Get, 1997; 2008).

The marketing concept asserts that the key to achieving organizational goals consists in determining the needs and wants of target markets and delivering the desired satisfaction more effectively and more efficiently than competitors. The more you learn about whom sport-tourists are where they are coming from and their motives and expectations for their visit, the better one can plan events and services. Intensive market analysis and research into people's tastes, preferences and attitudes are now the backbone of market planning. Market research is the tool for listening to customers. Before organizations can offer new events, they must understand what sport-tourists need, how they think, and what their questions are. Much of the marketing research process therefore aims to get close to the customer, thereby permitting the organization to understand the customer's perspective and needs.

Why is it important to gather information about sport tourists? (Green \& Jones, 2005)

The marketing concept asserts that the key to achieving organizational goals consists in determining the needs and wants of target markets and delivering the desired satisfaction more effectively and more efficiently than competitors. 
The more you learn about whom sport-tourists are, where they are coming from and their motives and expectations for their visit, the better one can plan events and services. Intensive market analysis and research into people's tastes, preferences and attitudes are now the backbone of market planning. Market research is the tool for listening customers. Before organizations can offer new events, they must understand what sport-tourists need, how they think, and what their questions are. Much of the marketing research process therefore aims to get close to the customer, thereby permitting the organization to understand the customer's perspective and needs. Marketing a sporting event requires a knowledge of which the potential sport-tourists are, what types of services and what they expect to get out of the experience itself. Keeping in touch with the marketplace requires regular assessment of customers, of customer needs and the relevant competitors in the environment. Just as any business must first define its competitive environment, an organization planning a sporting event must decide who its appropriate audience is and what services and goods that audience seeks. Marketing is fundamentally a process of supplying these products to meet a determined demand.

Vancouver's success in hosting sports events as diverse as the 2010 Olympic and Paralympic Winter Games, Canadian Football League's (CFL) Grey Cup, the World Police \& Fire Games, the World Wheelchair Rugby Championships, and the 2015 FIFA Women's World Cup soccer tournament continues to help bring new world-class sporting events to the city, including the new Canadian round of the World Rugby Sevens tournament.Vancouver is home to Canada's largest multi-purpose sports venue, BC Place Stadium, and boasts a multitude of other venues and facilities that can accommodate nearly any type and size of sporting event including hockey, baseball, soccer and cycling. Vancouver's mild west coast climate makes it ideal for outdoor pursuits such as running, golfing, sailing, cycling, tennis and mountain biking.Tourism Vancouver can help you with bid placement, site inspection and selection, facility and accommodation bookings, travel and excursion planning, as well as attendance-building and promotions. And through strategic partnerships, tourism Vancouver offers access to services such as a comprehensive online event-management tool, grants and other support for your event. Locals are passionate about sports and enthusiastically support four professional sports teams: Vancouver Canucks NHL hockey, BC Lions CFL football, Vancouver Canadians Single-A baseball, and Vancouver Whitecaps MLS soccer.

Sports tourism refers to international trips specifically taken to watch sporting events. Common examples include international Events such as world cups (soccer, rugby, Cricket, etc), the Olympics and Formula 1 Grand Prix, regional events (such as the Soccer European Champions League), and Individual (non-team) participant sports such as tennis, golf and horse racing. Sports tourists are more easily profiled according to the sports they follow.However, in general terms the bulk of the market tends to be young - between 18 and 34 years, and in the $\mathrm{C} 1$ and $\mathrm{C} 2$ (middle) socio-economic groups. This would also be the typical profile of a sports tourist following soccer matches. Rugby and cricket followers tend to be slightly older and with greater disposable income. Horse racing has a broad range of followers with no clear demographicStructure. Followers of athletics tend to be young, low spenders, whilst those Following the Formula 1 Grand Prix circuit tend to be skewed towards males in their 40s with above average disposable income.

The concept of sport related tourism has become more prominent in the last few years both as an academic field of study and an increasingly popular tourism product. The purpose of this paper is to review and critique the sport tourism literature as it stands in 1998, and to suggest a future research agenda. Disparities in the definition of sport tourism are addressed and some of the difficulties which scholars have faced in establishing a standardized definition are outlined. In answering the question why has sport tourism suddenly become so prominent, a look back at history shows that people have engaged in sport related travel for centuries. However, in the past ten years, the popularity of this form of travel has increased. Various explanations, such as the increased emphasis on health and fitness and increased use of sports events by cities to attract tourists, are examined. The question of what is known about sport tourism includes a review and critique of the literature in the three domains of sport tourism: active sport tourism, which refers to people who travel to take part in sport; event sport tourism, which refers to travel to watch a sports event; and nostalgia sport tourism, which includes visits to sports museums, famous sports venues, and sports themed cruises. The overarching conclusion from this review is that the field suffers from a lack of integration in the realms of policy, research, and education. At a policy level, there needs to be better coordination among agencies responsible for sport and those responsible for tourism. At a research level, more multi-disciplinary research is needed, particularly research which builds upon existing knowledge bases in both sport and tourism. In the realm of education, territorial contests between departments claiming tourism expertise and those claiming sport expertise need to be overcome.

\subsection{Study Problem}

This study seeks to find out the reality of recreational tourism programs that are provided for delegates to participate in organized sports youraments in Aqaba city located in Jordan, looking kinds of obstacles and difficulties facing this 
kind of tourism, and what implications affecting the development of this type of tourism.

\section{Literature Review}

Tourism organisations strongly depend on the strategically right employment of information systems and their knowledge-based applications. Indeed, several researchers consider the information systems and in particular the information technology (IT) and its flexibility as an enabler to achieve the desired competitive advantages, and as a crucial support to operational and strategic business decisions (Al Azmi, et al., 2012; Alenezi, et al., 2015; Alkalha, et al., 2012; Almajali \& Tarhini, 2016; Altamony et al., 2012; Kateb, et al., 2015; Maqableh \& Karajeh, 2014; Masa'deh, et al., 2016; Obeidat, et al., 2013; Shannak, et al., 2010, 2012; Tarhini et al., 2016; Vratskikh, et al., 2016); thus further research is required to examine the role of such IT applications in enhancing the managerial decisions. In addition, scholars (e.g. Masa'deh, et al. 2008; Hunaiti, et al., 2009; Masa'deh \& Kuk, 2009; Alshurideh, et al., 2012; Hajir, et al., 2015; Kannan \& Gharibeh, 2013; Masa'deh \& Shannak, 2012; Masa'deh, et al. 2017; Obeidat, et al., 2012, 2016; Shannak \& Alkour, 2012; Tarhini, et al., 2015) emphasize the need for large firms to integrate their IT systems with their KM strategies and processes in order to survive in their highly competitive business environments, which in turn could accelerate the managerial decisions as well.

Aldmour (2011) study seeks to identify the role of sporting event in the revitalization of touristic movement, the types of obstacles difficulties facing this type of tourism that hinder it from playing its desired role, pattern of discrimination it face, and their consequences that effect its desired performance. The golden triangle was used as a case study, type of tourism program and how to develop sports tourism in Jordan, this study reviews the relation between sporting events and touristic activates in the golden triangle: (Petra, Aqaba and Wadi Rum), this study adopted a carefully designed survey form to collect data and information, and to see the trends and views of the study sample, the results showed that sporting events available do not help to stimulate movement of sport tourism in Jordan, government legislation and regulation in force do not help stimulate movement of sports tourism in Jordan advertising available do not help yo stimulate movement of sports tourism in Jordan , the study recommended that the stakeholders pay more attention to by providing events and sports activities for tourists yet desirable quantitatively and qualitatively, the study recommends agencies to issue and devlop legislation and laws that are involved in sports tourism.

First combined sport and tourism together in a book in 1987. Hall (1992) defined sport tourism as travel for non-commercial reasons, to participate or observe sporting activities away from the home range. Gibson (1999) defined sport tourism as travel with the main purpose of leisure, tourists attend fitness activities, or watch sport activities or visit attractions related to sport activities. While in terms of the purpose of sport tourism, Standeven and De Knop (1998) argued that sport tourism also includes the category of business and commercial tourism, namely, sport tourism can also occur while a person is traveling for business or commercial purposes. As for the forms of sport tourism, Standeven and De Knop (1998) identified several types of sport tourism according to the purposes and contents of the travel, namely, tourists can participate for holiday or for business, be active or passive, to observe or be involved in, to be organized or independent, and so on.

Motivations of Sport Tourists As for the purposes of sport tourists, there are not only the purposes of general travel, which as American scholar G. Dann concluded, includes pull factors and pulling factors, sport tourism also involves some special purposes, such as fans and addicts in certain sports. Gibson, Willming \& Holdnak (2003) studied the motivations of fans as tourists to attend small-scale sport tourism events. Gibson (2005) made a study on the behaviors of sport tourists by reference to role theory, family life cycle theory, motivation theory, and the changes of social structure. Lisa, Heather \& Kenneth (2001) took the 1996 Atlanta Olympic Games as a case study and found that three most important factors affecting tourists' decisions in attending the sport events are: (1) an once-in-a-lifetime chance (29.7\%); (2) can solve the accommodation during the Olympic Games (11.3\%); and (3) can buy or acquire the Olympic Games tickets (8.4\%). And after making a decision, the biggest motivations to attend the Olympic Games were the wonderful sports competitions, culture experiences, and so on. Impacts of Sport Tourism International sport events always generate a great influence on the host countries and cities. Margaret (2007) analyzed the impacts of sport tourism on the basis of central place theory, stressing the influence of location features. Xiao, Shen \& Liu (2004) pointed out the influences of hosting large sport events on the host cities, such as enriching the tourism resources, improving the urban infrastructure, enhancing the cultural exchanges, etc. A series of studies were done by Ritchie to access the impacts of the Olympic Games. Taking the 1988 Olympic Winter Games as a case study, positive impacts were found like boosting the economy, enhancing the international image and reputation of the host city. Vincent (1995) mainly studied the environmental impacts of the 1992 Winter Olympic Games, both positive and negative environmental impacts on the local city. Hypotheses are as follows: H1: The tourists' influence perception of the Asian Winter Games has a path effect on their motivation perception. H2: The times that tourists have participated in sport 
tourism in the past two years have a path effect on their motivation perception of the Asian Winter Games. H3: The times that tourists have participated in sport tourism in the past two years have a path effect on their influence perception of the Asian Winter Games. Methodology Literature Review The authors make full use of the resources of the Internet, library, etc. and consult a large amount of domestic and foreign literature. Literature in Chinese and English includes studies on definitions and classification of sport tourism, studies on the tourists' motivations in participating in sport tourism, studies on the influence of sport tourism, studies on the current situation and development strategies of sport tourism, and case studies on some famous large sport games, such as the Olympic Games, the World Cup, etc.. Marketing Survey The questionnaire was preliminarily designed based on the review of domestic and foreign literature. After a pilot study, the questionnaire was corrected. The questionnaires were distributed in Astana city, Kazakhstan, during the Asian Winter Games to visitors from January 30, 2011 to February 6, 2011, combined with an in-depth interview. This study examined the relationship between the preferred leisure and tourism activities and psychological in paddling of a group of paddlers. Participants were surveyed at the completion of a paddle tour. Data were analyzed using frequencies, confirmatory factor analysis, cross-tabulation, and ANOVA, four types of leisure - tourism connection were identified people more highly involved with paddling tended to paddle while on vication compared with other LTC types. The findings provide empiral evidence for previous assertions proposing a connection between involvement in leisure activities and subsequent tourism behaviors (Chang \& Gibson, 2011).

The concept of sport related tourism has become more prominent in the last few years both as an academic field of study and an increasingly popular tourism product. The purpose of this paper is to review and critique the sport tourism literature as it stands in 1998, and to suggest a future research agenda. Disparities in the definition of sport tourism are addressed and some of the difficulties which scholars have faced in establishing a standardized definition are outlined. In answering the question why has sport tourism suddenly become so prominent, a look back at history shows that people have engaged in sport related travel for centuries. However, in the past ten years, the popularity of this form of travel has increased. Various explanations, such as the increased emphasis on health and fitness and increased use of sports events by cities to attract tourists, are examined. The question of what is known about sport tourism includes a review and critique of the literature in the three domains of sport tourism: active sport tourism, which refers to people who travel to take part in sport; event sport tourism, which refers to travel to watch a sports event; and nostalgia sport tourism, which includes visits to sports museums, famous sports venues, and sports themed cruises. The overarching conclusion from this review is that the field suffers from a lack of integration in the realms of policy, research, and education. At a policy level, there needs to be better coordination among agencies responsible for sport and those responsible for tourism. At a research level, more multi-disciplinary research is needed, particularly research which builds upon existing knowledge bases in both sport and tourism. In the realm of education, territorial contests between departments claiming tourism expertise and those claiming sport expertise need to be overcome.

\section{Research Methodology}

This section provides the methodology applied in the current study. It consists of the research model, operational definitions of the study's independent and dependent variables, research hypotheses, besides data collection tool and research population and sample.

\subsection{Research Model}

The elements of this research are established based on preceding literature, either theoretically or empirically. Indeed, this study used variables that are common in hotel management literature. Figure 1 represents a model for the study that shows the independent variables, the dependent variable and the proposed relationship between them. 


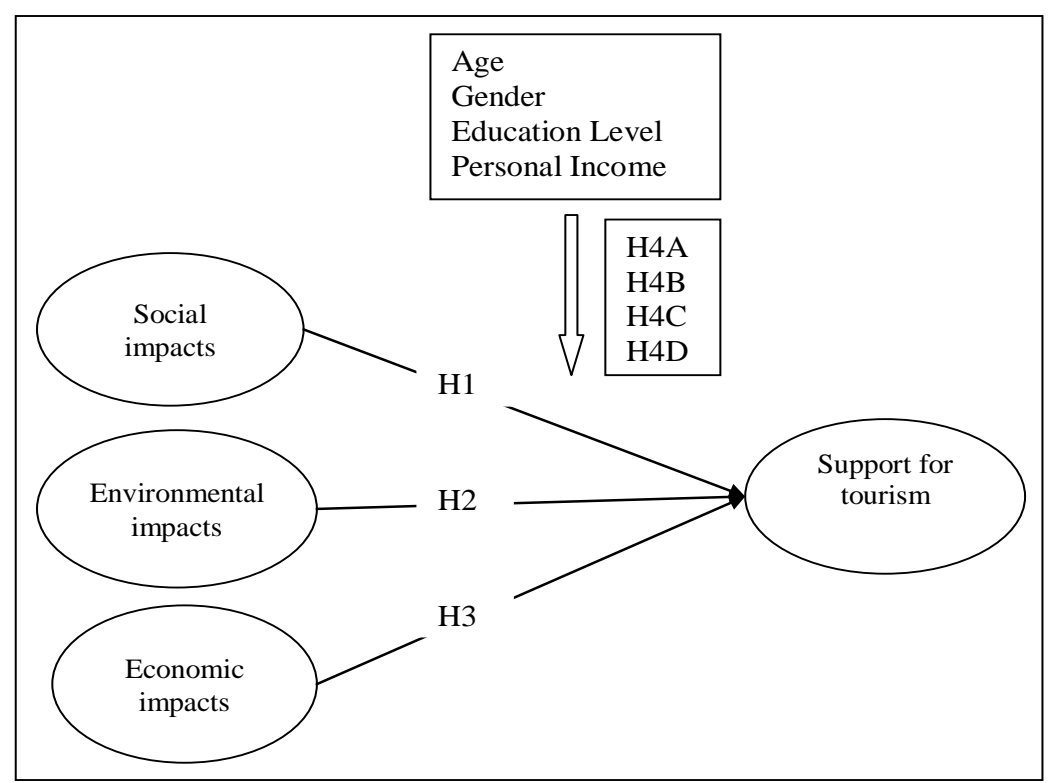

Figure 1. Research Model

\subsection{Operational Definitions}

Adapted from Hritz \& Ross (2010) and Nunkoo \& Ramkissoon (2011), the current research considers the construct of sport tourism in terms of three independent variables (i.e. social impacts, environmental impacts, and economic impacts) on support for tourism development; which were measured in the research questionnaire through five, five, five, and four items respectively.

\subsection{Research Hypotheses}

In order to test the research model of the impact of sport tourism on support for tourism development, the study is hypothesized as follows:

H1: There is a statistically significant impact of social impacts on support for tourism development.

$\mathrm{H} 2$ : There is a statistically significant impact of environmental impacts on support for tourism development.

H3: There is a statistically significant impact of economic impacts on support for tourism development.

H4A: There is a significant difference in the impact of sport tourism on support for tourism development due to gender.

H4B: There is a significant difference in the impact of sport tourism on support for tourism development due to age.

H4C: There is a significant difference in the impact of sport tourism on support for tourism development due to educational level.

H4D: There is a significant difference in the impact of sport tourism on support for tourism development due to personal income.

\subsection{Population and Sampling}

The study population consisted of all spectrums of the community interested in tourism in Aqaba city includes all age levels (from 18 to 40 years and above). 480 questionnaires were returned and considered for statistical analysis. The questionnaire consisted of two sections; the first section in questionnaire presents general personal information about a respondent, the gender, age, educational level, and personal income. The second section includes questions to measure the independent and dependent variables based on their operational definitions.

\section{Data Analysis and Results}

In order to explore the impact of sport tourism on support for tourism development, in which these variables have been measured using 5-points Likert scale that varies between strongly disagree $=1$ and strongly agree $=5$. Also, reliability and validity analyses were conducted, descriptive analysis was used to describe the characteristic of sample and the respondent to the questionnaires besides the independent and dependent variables. Also, multiple 
regression analysis was employed to test the research hypotheses.

\subsection{Validity and Reliability}

Validity and reliability are two important measures to determine the quality and usefulness of the primary data. Validity is about accuracy and whether the instrument measures what it is intended to measure while reliability is about precision; it is used to check the consistency and stability of the questionnaire. Indeed, the researchers depended on scales and items that were previously developed and used by other researchers with similar interest. Also a draft of the questionnaire was formulated, and then it was reviewed by four academic lecturers -who have a sufficient knowledge and experience in this scope- to insure that each item is measuring what is intended to be measured, and to avoid the ambiguity and complexity in the phrasing of questions. The reliability of the instrument was measured by the Cronbach's alpha coefficient. Further, some scholars (e.g. Bagozzi \& Yi, 1988) suggested that the values of all indicators or dimensional scales should be above the recommended value of 0.60 . Table (1) represents the results of Cranach's alpha for the independent and dependent variables. Cronbach's alpha coefficients of all the tested variables are above 0.60 which suggesting the composite measure is reliable.

Table 1. The Cronbach's alpha coefficients of study variables

\begin{tabular}{lcc}
\hline Variables & Number of items & Cronbach alpha \\
\hline Social impacts & 5 & 0.645 \\
Environmental impacts & 5 & 0.627 \\
Economic impacts & 5 & 0.666 \\
Support for tourism development & 4 & 0.678 \\
\hline
\end{tabular}

\subsection{Respondents Demographic Profile}

As indicated in Table 2, the demographic profile of the respondents for this study showed that they are typically males, most of them between 18-30 years old, the majorities hold high school and diploma degrees; and most of them earn less than $750 \$$ monthly.

Table 2. Description of the respondents' demographic profiles

\begin{tabular}{|c|c|c|c|}
\hline Category & Category & Frequency & Percentage \% \\
\hline \multirow[t]{3}{*}{ Gender } & Males & 269 & 56.0 \\
\hline & Females & 211 & 44.0 \\
\hline & Total & 480 & 100 \\
\hline \multirow[t]{5}{*}{ Age } & 18 years - less than 25 & 105 & 21.9 \\
\hline & 25 years - less than 30 & 222 & 46.3 \\
\hline & 30 years - less than 40 & 101 & 21.0 \\
\hline & More than 40 years old & 52 & 10.8 \\
\hline & Total & 480 & 100 \\
\hline \multirow[t]{7}{*}{ Education level } & Less than high school & 54 & 11.3 \\
\hline & High school & 176 & 36.7 \\
\hline & Diploma & 123 & 25.6 \\
\hline & Bachelor & 94 & 19.6 \\
\hline & Master & 28 & 5.8 \\
\hline & Doctorate & 5 & 1.0 \\
\hline & Total & 568 & 100 \\
\hline \multirow{4}{*}{$\begin{array}{l}\text { Personal income }(\$) \\
\text { monthly }\end{array}$} & Less than 750 & 321 & 65.0 \\
\hline & 750- less than 1500 & 137 & 28.5 \\
\hline & More than 1500 & 31 & 6.5 \\
\hline & Total & 480 & 100 \\
\hline
\end{tabular}




\subsection{Descriptive Analysis}

In order to describe the responses and thus the attitude of the respondents toward each question they were asked in the survey, the mean and the standard deviation were estimated. While the mean shows the central tendency of the data, the standard deviation measures the dispersion which offers an index of the spread or variability in the data (Sekaran \& Bougie, 2013). In other words, a small standard deviation for a set of values reveals that these values are clustered closely about the mean or located close to it; a large standard deviation indicates the opposite. The level of each item was determined by the following formula: (highest point in Likert scale - lowest point in Likert scale) / the number of the levels used $=(5-1) / 5=0.80$, where 1-1.80 reflected by "very low", 1.81-2.60 reflected by "low", 2.61-3.40 reflected by "moderate", 3.41-4.20 reflected by "high", and 4.21-5 reflected by "very high". Then the items were being ordered based on their means. Tables 3 and 4 show the results.

Table 3. Overall mean and standard deviation of the study's variables

\begin{tabular}{clcccc}
\hline $\begin{array}{c}\text { Type of } \\
\text { Variable }\end{array}$ & Variables & Mean & $\begin{array}{c}\text { Standard } \\
\text { Deviation }\end{array}$ & Level & Order \\
\hline $\begin{array}{c}\text { Independent } \\
\text { Variables }\end{array}$ & Social impacts & 3.26 & 0.58 & Moderate & 3 \\
\hline & Environmental impacts & 3.32 & 0.59 & Moderate & 2 \\
\hline $\begin{array}{c}\text { Dependent } \\
\text { Variable }\end{array}$ & Economic impacts & 3.47 & 0.56 & High & 1 \\
\hline
\end{tabular}

As presented in Table 3, data analysis results have shown that residents' support for tourism development in Aqaba is applied to a high level in which the mean score is 3.72. Also, economic impacts is applied to a high level as the mean score is 3.42, wheras both environmental and social impacts do exist moderatley and respectively. Table 4 demonstrates the mean, standard deviations, level, and order scores the items for each variable.

Table 4. Mean and standard deviation of the study's variables

\begin{tabular}{lcccc}
\hline Social impacts & Mean & SD & Level & Order \\
\hline Sport tourism has decreased the crime rate in Aqaba city & 2.48 & 1.159 & Low & 5 \\
\hline $\begin{array}{l}\text { Local residents have not suffered from living in a sport tourism } \\
\text { destination area }\end{array}$ & 2.97 & 0.948 & Moderate & 4 \\
\hline $\begin{array}{l}\text { Sport tourism has encouraged a variety of cultural activities by the } \\
\text { local residents }\end{array}$ & 3.37 & 0.902 & Moderate & 3 \\
\hline $\begin{array}{l}\text { Meeting sport tourists from other regions is a valuable experience to } \\
\text { understand their culture and society }\end{array}$ & 3.69 & 0.874 & High & 2 \\
\hline $\begin{array}{l}\text { Sport tourism has resulted in positive impacts on the cultural identity of } \\
\text { Aqaba city }\end{array}$ & 3.82 & 1.030 & High & 1 \\
\hline Environmental impacts & Mean & SD & Level & Order \\
\hline Sport tourism provides more parks and other recreational areas & 3.24 & 1.270 & Moderate & 4 \\
\hline $\begin{array}{l}\text { Our roads and public facilities are kept at a high standard due to sport } \\
\text { tourism }\end{array}$ & 3.39 & 0.962 & Moderate & 2 \\
\hline $\begin{array}{l}\text { Sport tourism has provided an incentive for the restoration of historical } \\
\text { buildings and the conservation of natural resources }\end{array}$ & 3.37 & 0.945 & Moderate & 3 \\
\hline $\begin{array}{l}\text { Sport tourism has not resulted in traffic congestion, noise and pollution } \\
\text { Construction of sport tourist facilities has not destroyed the natural }\end{array}$ & 3.15 & 1.042 & Moderate & 5 \\
\hline $\begin{array}{l}\text { environment } \\
\text { Economic impacts }\end{array}$ & Mean & SD & Level & Order \\
\hline
\end{tabular}




\begin{tabular}{lcccc}
\hline Sport tourism has created more jobs for local people & 2.97 & 1.158 & Moderate & 5 \\
\hline Sport tourism has given economic benefits to small businesses & 3.44 & 0.967 & High & 3 \\
\hline $\begin{array}{l}\text { My standard of living has increased considerably because of sport } \\
\text { tourism }\end{array}$ & 3.32 & 0.895 & Moderate & 4 \\
\hline $\begin{array}{l}\text { The prices of goods and services have increased because of sport } \\
\text { tourism }\end{array}$ & 3.75 & 0.940 & High & 2 \\
\hline The cost of developing sport tourism facilities is high & 3.89 & 1.001 & High & 1 \\
\hline Support for tourism development & Mean & SD & Level & Order \\
\hline Sport tourism is one of the most important industries Aqaba city & 3.50 & 1.117 & High & 4 \\
\hline Sport tourism helps my community grow in the right direction & 3.71 & 0.875 & High & 2 \\
\hline Sport tourism continues to play an important economic role & 3.63 & 0.874 & High & 3 \\
\hline I am proud that tourist are coming to Aqaba city & 4.06 & 0.824 & High & 1 \\
\hline
\end{tabular}

\subsection{Hypotheses Testing Results}

The current research is mainly seeking to investigate the impact of sport tourism in terms of social impacts, environmental impacts, and economic impacts on support for tourism development in Aqaba city in Jordan. Consequently, in order to test the hypotheses developed for this study, multiple regression technique was used. Further, the level of significance ( $\alpha$-level) was chosen to be 0.05 and the probability value (p-value) obtained from the statistical hypotheses test is considered to be the decision rule for rejecting the null hypotheses (Creswell, 2009). If the p-value is less than or equal to $\alpha$ - level, the null hypothesis will be rejected and the alternative hypothesis will be supported. However, if the p-value is greater than the $\alpha$-level, the null hypothesis cannot be rejected and the alternative hypothesis will not be supported. In addition, normality of the independent variables and the absence of multi co-linearity problem (a case of multiple regression in which the independent variables are themselves highly correlated) were checked. According to Pallant (2005), most of the values should be inside the adequate ranges for normality (i.e. -1.0 to +1.0 ). For this purpose, skewness and Variance Inflation Factor (VIF) were investigated; Table 5 includes the results.

Table 5. Skewness and VIF for the independent variables

\begin{tabular}{lccc}
\hline Variables & Tolerance & VIF & Skewness \\
\hline Social impacts & 0.885 & 1.131 & 0.884 \\
\hline Environmental impacts & 0.849 & 1.178 & 0.848 \\
\hline Economic impacts & 0.909 & 1.100 & 0.909 \\
\hline
\end{tabular}

As can be noticed from Table 5, the skewness values were within the normal values $(-1.0$ to +1.0$)$ suggesting that the data of the independent variables is normal. The VIF values were less than the critical value (10) which is most common among the most studies, suggesting no multi co-linearity problem among the independent variables. However, the results of testing the three hypotheses are demonstrated in Table 6.

Table 6. Result for the study model (b)

\begin{tabular}{|c|c|c|c|c|c|c|c|}
\hline Variable & $\mathbf{r}$ & $\mathbf{R}^{2}$ & f & Sig (f) & $\boldsymbol{\beta}$ & $\mathbf{t}$ & Sig (t) \\
\hline Social impacts & 0.544 & 0.295 & 16.458 & $0.000 \mathrm{a}$ & 0.042 & 0.856 & 0.393 \\
\hline Environmental impacts & & & & & 0.103 & 2.082 & 0.038 \\
\hline Economic impacts & & & & & 0.274 & 5.465 & 0.000 \\
\hline
\end{tabular}

a. Predictors: (Constant), Social impacts, Environmental impacts, Economic impacts

b. Dependent variable: Support for tourism development 
Refer to Table 6 the multiple correlation coefficient $\mathrm{R}=0.544$ indicates that there is a strong positive correlation between the independent variables (social impacts, environmental impacts, and economic impacts) and support for tourism development. The $\mathrm{R}^{2}$ indicated the generalizability of the model. It allows us to generalize the results taken from the respondents to the whole population. In this case it equals 0.295 . The results showed that F-ratio for these data is equal to 16.458 , which is statistically significant at $p<0.05$. Therefore, we conclude that there is a statistically significant impact of the independent variables on residents' support for tourism development.

The $\beta$ indicates the individual contribution of each predictor (independent variable) to the model, if other predictors are held constant. Table 6 shows the standardized coefficients for each independent variable. The value of $\beta$ for environmental impacts and economic impacts are 0.103 , and 0.274 respectively, which are positive, thus $\mathrm{H} 2$ and $\mathrm{H} 3$ were supported. While for social impacts; the value of $\beta$ is 0.042 , which have small values compared with other predictors, and not significant at $\mathrm{p} \leq 0.05$; thus $\mathrm{H} 1$ was not supported. The level of effect of these variables depends on the $\beta$ value, the higher $\beta$ value the higher effect on dependent variable. We can infer from the values of beta that the variable that has the highest contribution in the model is economic impacts, followed by environmental impacts.

Hypotheses H4A, H4B, H4C, H4D argued that there is a significant difference in the impact of sport tourism on support for tourism development due to gender, age, educational level, and personal income. Independent Samples T-test was employed in order to investigate if there any significant differences in the impact of sport tourism on support for tourism development that can be attributed to gender. Also, ANOVA test was employed to examine if there any significant differences in the impact of sport tourism on support for tourism development can be attributed to age, educational level, and personal income. Results of T-test, shown in Table 7, indicated that there is no significant difference in the impact of resident attitudes towards sustainable tourism development that can be attributed to gender. However, results of ANOVA test, shown in Table 8 and Table 9 indicated that there is no significant difference in the impact of resident attitudes towards sustainable tourism development in favor of age and educational level; whereas a significant difference in favor of personal income was found, see Table 10.

Table 7. T-test of the impact of sport tourism on support for tourism development due to gender

\begin{tabular}{|c|c|c|c|c|c|c|c|c|c|}
\hline \multirow[b]{2}{*}{ Variables } & \multicolumn{3}{|c|}{ Male } & \multicolumn{3}{|c|}{ Female } & \multirow{2}{*}{$\mathbf{T}$} & \multirow{2}{*}{ df } & \multirow{2}{*}{ Sig } \\
\hline & $\mathbf{N}$ & Mean & Std. Dev. & $\mathbf{N}$ & Mean & Std. Dev. & & & \\
\hline $\begin{array}{l}\text { Support for } \\
\text { tourism } \\
\text { development }\end{array}$ & 211 & 3.7429 & 0.62436 & 269 & 3.7119 & 0.61290 & 0.544 & 447.222 & 0.587 \\
\hline
\end{tabular}

Table 8. ANOVA Analysis of the impact of sport tourism on support for tourism development due to age

\begin{tabular}{ccccccc}
\hline Variables & \multicolumn{1}{c}{$\begin{array}{c}\text { Sum of } \\
\text { Squares }\end{array}$} & Df & $\begin{array}{c}\text { Mean } \\
\text { Square }\end{array}$ & F & Sig. \\
\hline $\begin{array}{c}\text { Support for tourism } \\
\text { development }\end{array}$ & $\begin{array}{c}\text { Between } \\
\text { Groups }\end{array}$ & 0.484 & 3 & 0.161 & 0.421 & 0.738 \\
\cline { 2 - 7 } & $\begin{array}{c}\text { Within } \\
\text { Groups }\end{array}$ & 182.166 & 476 & 0.383 & & \\
\cline { 2 - 6 } & Total & 182.650 & 479 & & & \\
\hline
\end{tabular}


Table 9. ANOVA Analysis of the impact of sport tourism on support for tourism development due to educational level

\begin{tabular}{ccccccc}
\hline Variables & \multicolumn{2}{c}{$\begin{array}{c}\text { Sum of } \\
\text { Squares }\end{array}$} & Df & $\begin{array}{c}\text { Mean } \\
\text { Square }\end{array}$ & F & Sig. \\
\hline $\begin{array}{c}\text { Support for tourism } \\
\text { development }\end{array}$ & $\begin{array}{c}\text { Between } \\
\text { Groups }\end{array}$ & 2.379 & 5 & 0.476 & 1.251 & 0.284 \\
\cline { 2 - 4 } & $\begin{array}{c}\text { Within } \\
\text { Groups }\end{array}$ & 180.271 & 474 & 0.380 & & \\
\cline { 2 - 5 } & Total & 182.650 & 479 & & \\
\hline
\end{tabular}

Table 10. ANOVA Analysis of the impact of sport tourism on support for tourism development due to personal income

\begin{tabular}{ccccccc}
\hline Variables & \multicolumn{1}{c}{$\begin{array}{c}\text { Sum of } \\
\text { Squares }\end{array}$} & Df & $\begin{array}{c}\text { Mean } \\
\text { Square }\end{array}$ & F & Sig. \\
\hline $\begin{array}{c}\text { Support for tourism } \\
\text { development }\end{array}$ & $\begin{array}{c}\text { Between } \\
\text { Groups }\end{array}$ & 3.630 & 2 & 1.815 & 4.836 & 0.008 \\
\cline { 2 - 5 } & $\begin{array}{c}\text { Within } \\
\text { Groups }\end{array}$ & 179.020 & 477 & 0.375 & & \\
\cline { 2 - 5 } & Total & 182.650 & 479 & & \\
\hline
\end{tabular}

\section{Discussion and Conclusions}

This section contains to view the findings of the study, which aimed to measure the impact of sport tourism (by using the variables of social impacts, environmental impacts, and economic impacts) on support for tourism development from the local residents in Aqaba city.

\subsection{Results}

Many people wonder what sports tourism is. Sports tourism is traveling from one region, country, state, etc. to another in order to watch a sports competition or game. While sports tourism has not always been extremely popular, during the recent decade the amount of people attending out of area sporting events has drastically increased. People are now traveling far and wide just to attend their favorite events, and it is no wonder as to what has encouraged the sudden spike in popularity. Sports tourism involves traveling to specific locations to watch sporting events or to participate in sports. Many travel firms market all inclusive travel deals which include tickets to sporting events, accommodation and meals for sports fans. Some people prefer to make their own travel arrangements and buy transportation and event tickets without the assistance of travel agents.

On the one hand, the host countries have to spend a huge deal of money to plan these events. The money is expended in the form of construction of the infrastructure of the country to cater the needs of the athletes or sportspeople. These apart, in order to build arenas and stadiums governments have to invest millions of dollars which can be better spent on other more significant sectors such as healthcare and education which incur prosperity for the host country. In addition to this, the host governments compromise with facility to be provided to its citizens. On many occasion, these nations have to face financial insolvency due to huge expenditures on sports events. Apparently, these arrangements entail a number of concerns. On the other hand, these types of events bring a wide array of positives too. The first and foremost advantage of hosting international events is that the host country becomes the centre of attention and these events bring prestige and honour to the country. Secondly, although these events consumes too much money to be organised, the host countries, in fact, can generate their revenue by opening tourist visas for sports lovers which can engender government income by the means of tourism. These apart, the infrastructure that is improved to cater for sports people would also contributes to that nations prosperity. Therefore, the advantages are immense.

Sport tourism is considered the most important types of tourism, the spectrum because it satisfies the desire of tourists from two sides, a sports and entertainment together. As for tourism sports in the area of Aqaba it is not limited to water sports only, but there are many sports activities such as marathon Red Sea and the castle Marathon. The area is considered an authority Aqaba Special Economic One supporter Tours in general and in particular 
tourism Sport. In addition, Aqaba is the coastal city and practiced many water sports as fishing, diving and swimming, it is possible to develop this type of tourism to take action, such as a new sports recreational boat race and the creation of City of the Games and aquatic promotion.

Tourism general concept aimed at self-entertainment to get rid of the pressures faced by the people in terms of (work-social life in general) worked tourism on the follow-up to people's concerns appeared new types of tourism such as sports tourism were collected between entertainment and exercise (Alsarayreh, 2012). Anyone loving sports be exercised constantly, even if he had to travel for tourism and met with sports tourism have a large turnout by the competent authorities, especially in the city of Aqaba, being one of the most popular tourist cities in Jordan, which led to the emergence of water sport where full ingredient required for these activities, and received plenty of interest from the available different people regardless of their social strata and interest in addition to that we worked for the Aqaba Special economic zone authority to provide full support of the physically and morally and attracted corporate sponsors of these activities and provide them with all the requirements of even the tourism activities up to the highest levels in Jordan in Aqaba in particular, became the city of Aqaba hosts tournaments for swimming and athletes participate from various Arab nationalities and even explain the concept of sports tourism in this activity has become a hurdle authority offers participants the full tourist program in Aqaba and sometimes in Jordan, which contributed to the intellectual progress of the local community in sports tourism and the possibility of participation and the opportunity offered to discover the talents of the local community and provided full support to them and is held annually in the city of Aqaba activities (such as Marathon Red Sea - a bicycle race - race cars) where all these activities. We worked on the show meaning real sports tourism and became visitors from different governorates of the Kingdom comes to attend these activities which shows the success of sports tourism in the city of Aqaba and the competent authorities are working on the development of the city of Aqaba positively contribute to raising the level of sports tourism in all its aspects.

It considers sports tourism of the most important types of favorite tourism at the present time, because they are based entertainment for tourists and is at the same time of exercise leading to earn interest of sports tourism, where most of the people may be linked to the exercise of a particular type of sport that cannot be left in permanently, sports tourism in Jordan in general and considered in Aqaba in particular of the newest types of tourism, which provides practice water sports, as it is considered at present one of the most desirable types of tourism with tourists. The convergence of sports tourism in Aqaba large turnout by the competent authorities, in addition to the support provided for projects that promote sports tourism, such as the Red Sea Marathon, which is held annually in the city of Aqaba, and is considered the Aqaba Special Economic Zone Authority first supporter of this event, where he encouraged the local community the companies responsible for sports activities to participate in two ways: (material support, moral support), is also working to raise the intellectual level with the local community and providing all kinds of necessary support.

\subsection{Recommendations}

The current study recommends that researchers should provide more studies about sports tourism in Aqaba, and we advise others who are interested to apply the study to other regions. We do advise to take broader topics in sports tourism. Also, researchers who are interested can take advantages of the current study and apply it by working on the development and reconstruction of the sports places that bring tourists to be a tourism destination; interest in water sports and create new sports games to bring tourists to it; making sports competitions such as the swimming competition and host people from other countries; building up different courts such as basketball and golf courses; attracting young people under the age of 18 years to work in friendly matches in equipped for these activities stadiums; and making a marathon periodically to bring tourists.

\section{References}

Abbasi, M. S., Elyas, T., \& Shah, F. (2015). Impact of individualism and collectivism over the individual's technology acceptance behaviour: A multi-group analysis between Pakistan and Turkey. Journal of Enterprise Information Management, 28(6), 747-768. https://doi.org/10.1108/JEIM-12-2014-0124

Al Azmi, N., Al-Lozi, M., Al-Zu'bi, Z., \& Dahiyat, S., (2012). Patients Attitudes toward Service Quality and its Impact on their Satisfaction in Physical Therapy in KSA Hospitals. European Journal of Social Sciences, 34(2), 300-314.

Al-Badi, A., \& Al-Kaaf, W. (2017). Financial Incentives for Adopting Cloud Computing in Higher Educational Institutions. Asian Social Science, 13(4), 162-174. https://doi.org/10.5539/ass.v13n4p162

Al-Badi, A., \& Al-Sawaei, S. (2017). Utilizing Social Media to Encourage Domestic Tourism in Oman. 
International Journal of Business and Management, 12(4), 84-94. https://doi.org/10.5539/ijbm.v12n4p84

Al-Badi, A. H., \& Al-Qayoudhi, W. S. (2014). Adoption of social networks in business: Study of users and potential users in Oman. The International Business \& Economics Research Journal (Online), 13(2), 401-415. https://doi.org/10.19030/iber.v13i2.8457

Al-Dmour, H. (2011). The Role of Sports Events in the Revitalization of Touristic Movement from the Perspective of the Tourist (Golden Triangle Case Study). Research Journal of International Studies, 21, 159-168.

Al-Dmour, H., Al-Madani, S., Alansari, I., \& Al-Dmour, R. (2016). Factors Affecting the Effectiveness of Cause-Related Marketing Campaign: Moderating Effect of Sponsor-Cause Congruence. International Journal of Marketing Studies, 8(5), 114-127. https://doi.org/10.5539/ijms.v8n5p114

Al-Dmour, R., \& Obeidat, B. (2015). Strategic IT-Business Alignment as Managers' Explorative and Ecploitative Strategies. European Scientific Journal, 11(7), 437-457.

Alenezi, H., Tarhini, A., \& Masa'deh, R. (2015). Investigating the Strategic Relationship between Information Quality and E-Government Benefits: A Literature Review. International Review of Social Sciences and Humanities, 9(1), 33-50.

Alkalha, Z., Al-Zu'bi, Z., \& Alshurideh, M. (2012). Investigating the Effects of Human Resource Policies on Organizational Performance: An Empirical Study on Commercial Banks Operating in Jordan. European Journal of Economics, Finance and Administrative Sciences, 51, 44-64.

Allam, M., \& Elyas, T. (2016). Perceptions of Using Social Media as an ELT Tool among EFL Teachers in the Saudi Context. English Language Teaching, 9(7), 1-9. https://doi.org/10.5539/elt.v9n7p1

Almajali, D., \& Tarhini, A. (2016). Antecedents of ERP Systems Implementation Success: A Study on Jordanian Healthcare Sector. Journal of Enterprise Information Management, 29(4), 549-565. https://doi.org/10.1108/JEIM-03-2015-0024

Al-Qirim N., Tarhini, A., Rouibah, K. (2017). Determinants of Big Data Adoption and Success. In International Conference on Communications and Future Internet (ICCFI 2017). Jeju Island, South Korea, 10-13 August.

Alqahtani, M. A., Al-Badi, A. H., \& Mayhew, P. J. (2012). The Enablers and Disablers of E-Commerce: Consumers' Perspectives. The Electronic Journal of Information Systems in Developing Countries, 54(1), 1-25.

Alrowwad, A., Obeidat, B.Y., \& Aqqad, N. (2017). The impact of transformational leadership on organizational performance via the mediating role of corporate social responsibility: A structural equation modeling approach. International Business Research, 10(1), 199-221. https://doi.org/10.5539/ibr.v10n1p199

Alsarayreh, M. (2012). The Challenges Facing Sports Tourism for Special Needs Groups in Jordan. Global Journal of Humam Social Science, 12(3).

Alshurideh, M., \& Alkurdi, B. (2012). The Effect of Customer Satisfaction on Customer Retention in the Jordanian Mobile Market: An Empirical Investigation. European Journal of Economics, Finance and Administrative Sciences, 47, 69-78.

Altamony, H., \& Alshurideh, M., (2012). Information Systems for Competitive Advantage: Implementation of an Organizational Strategic Management Process. Proceedings of the 18th IBIMA Conference on Innovation and Sustainable Economics.

Altamony, H., Al-Salti, Z., Gharaibeh, A., \& Elyas, T. (2016). The relationship between Change Management Strategy and Successful Enterprise Resource Planning (ERP) Implementations: A Theoretical Perspective. International Journal of Business Management and Economic Research, 7(4), 690-703.

Bagozzi, R., \& Yi, Y. (1988). On the Evaluation of Structural Evaluation Models. Journal of the Academy of Marketing Science, 16(1), 74-94. https://doi.org/10.1007/BF02723327

Bisharat, H., Alrowwad, A., \& Mukattash, I. (2017). The Effect of Human Resource Management Practices on Organizational Commitment in Chain Pharmacies in Jordan. International Journal of Business and Management, 12(1). 50-67. https://doi.org/10.5539/ijbm.v12n1p50

Chang, S., \& Gibson, H. (2011). Phisically Active Leisure and Tourism Connection: Leisure Involvment and Choice of Tourism Activites among Paddlers. Leisure Sciences: An Interdisciplinary Journal, 33(20), 162-181. https://doi.org/10.1080/01490400.2011.550233

Creswell, J. (2009). Research Design: Qualitative, Quantitative, and Mixed Methods Approaches (3rd ed.). 
Thousand Oaks: Sage Publications.

El-Masri, M., \& Tarhini, A. (2015). A Design Science Approach to Gamify Education: From Games to Platforms. Twenty-Third European Conference on Information Systems (ECIS), Münster, Germany. 26-29 May 2015.

El-Masri, M., \& Tarhini, A. (2017). Factors affecting the adoption of e-learning systems in Qatar and USA: Extending the Unified Theory of Acceptance and Use of Technology 2 (UTAUT2). Educational Technology Research and Development, 65(3), 743-763. https://doi.org/10.1007/s11423-016-9508-8

El-Masri, M., Orozco, J., Tarhini, A., \& Tarhini, T. (2015). The Impact of IS-Business Alignment Practices on Organizational Choice of IS-Business Alignment Strategies. The 19th Pacific Asia Conference on Information Systems (PACIS 2015), Paper 215, Singapore, 6-9 July 2015.

Elyas, T., \& Picard, P. (2012). Teaching and Moral Tradition in Saudi Arabia: A Paradigm of Struggle or Pathway towards Globalization?. Procedia - Social and Behavioral Sciences, 41, 1083-1086. https://doi.org/10.1016/j.sbspro.2012.06.782

Fedai, L., Daglı, G., Altınay, Z., \& Altınay, F. (2017). The examination of occupational burnout and job satisfaction of the physical education teachers. International Journal of Economic Perspectives, 11(1), 12-26.

Get, D. (1997). Event Management of Event Tourism. Cognizant Communication Group.

Get, D. (2008). Event Tourism: Definition, Evaluation and Research. Tourism Management, 29(3), 403-428. https://doi.org/10.1016/j.tourman.2007.07.017

Gibson, H. (1989). Sport Tourism: A Critical Analysis of Reserch. Sport Management Review, 1(1), 45-69.

Green, C., \& Jones, I. (2005). Serious Leisure, Social Identity and Sport Tourism. Sport in Society: Cultures, Commerce, Media, Politics, 8(2), 164-181. https://doi.org/10.1080/174304305001102010

Hajir, J., Obeidat, B., \& Al-dalahmeh, M. (2015). The Role of Knowledge Management Infrastructure in Enhancing Innovation at Mobile Telecommunication Companies in Jordan. European Journal of Social Sciences, 50(3), 313-330.

Hamoud, M., Akour, M. A., \& Al-Salti, Z. (2016). Developing the Main Knowledge Management Process via Social Media in the IT Organisations: A Conceptual Perspective. International Journal of Business Administration, $7(5), 49-64$.

Hritz, N., \& Ross, C. (2010). The Perceived Impacts of Sport Tourism: An Urban Host Community Perspective. Journal of Sport Management, 24, 119-138. https://doi.org/10.1123/jsm.24.2.119

Hassouna, M., Elyas, T., \& Abou Trab, M. S. (2015). Customer Churn in Mobile Markets: A Comparison of Techniques. International Business Research, 8(6), 224-237. https://doi.org/10.5539/ibr.v8n6p224

Hussian, A., Elyas, T., \& Nasseef, O. (2013). Research Paradigms: A Slippery Slope for Fresh Researchers. Life Science Journal, 10(4), 2374-2381.

Hunaiti, Z., Mansour, M., \& Al-Nawafleh. (2009). Electronic Commerce Adoption Barriers in Small and Medium-Sized Enterprises (SMEs) in Developing Countries: The Case of Libya. IBIMA Business Review, 2(5), $37-45$.

Kanaan, R., \& Gharibeh, A. (2013). The Impact of Knowledge Sharing Enablers on Knowledge Sharing Capability: An Empirical Study on Jordanian Telecommunication Firms. European Scientific Journal, 9(22), $237-258$.

Kateb, M., Swies, R., Obeidat, B., \& Maqableh, M. (2015). An Investigation on the Critical Factors of Information System Implementation in Jordanian Information Technology Companies. European Journal of Business and Management, 7(36), 11-28.

Mahadeen, B., Al-Dmour, R., \& Obeidat, B. Y. (2016). Examining the effect of the Organization's Internal Control System on Organizational Effectiveness: A Jordanian empirical study. International Journal of Business Administration, 7(6), 22-41. https://doi.org/10.5430/ijba.v7n6p22

Maqableh, M., \& Karajeh, H. (2014a). Job Scheduling for Cloud Computing Using Neural Networks. Communications and Network, 6(3), 191. https://doi.org/10.4236/cn.2014.63021

Maqableh, M., \& Karajeh, H. (2014b). A Theoretical Perspective on the Relationship between Leadership Development, Knowledge Management Capability, and Firm Performance. Asian Social Science, 10(6), 128.

Masa'deh, R. (2013). The Impact of Information Technology Infrastructure Flexibility on Firm Performance: An 
Empirical Study of Jordanian Public Shareholding Firms. Jordan Journal of Business Administration, 204-224. https://doi.org/10.12816/0002054

Masa'deh, R., \& Kuk, G. (2009). Antecedents and Intermediaries between Strategic Alignment and Firm Performance. Conference of the Academy of Management Annual Meeting (AOM), Illinois, Chicago, USA.

Masa'deh, R., Gharaibeh, A., Maqableh, M., \& Karajeh, H. (2013a). An Empirical Study of Antecedents and Outcomes of Knowledge Sharing Capability in Jordanian Telecommunication Firms: A Structural Equation Modeling Approach. Life Science Journal, 10(4), 2284-2296.

Masa'deh, R., Hunaiti, Z., \& Bani Yaseen, A. (2008). An Integrative Model Linking IT-Business Strategic Alignment and Firm Performance: The Mediating Role of Pursuing Innovation and Knowledge Management Strategies. Communications of the International Business Information Management Association (IBIMA) Journal, 2(24), 180-187.

Masa'deh, R., Shannak, R., \& Maqableh, M. (2013b). A Structural Equation Modeling Approach for Determining Antecedents and Outcomes of Students' Attitude toward Mobile Commerce Adoption. Life Science Journal, $10(4), 2321-2333$.

Masa'deh, R., Tayeh, M., Al-Jarrah, I., \& Tarhini, A. (2015c). Accounting vs. Market-based Measures of Firm Performance Related to Information Technology Investments. International Review of Social Sciences and Humanities, 129-145.

Masa'deh, R. (2012). The Impact of Management Information Systems (MIS) on Quality Assurance (QA): A Case Study in Jordan. International Journal of Information, Business, and Management, 93-110.

Masa'deh, R., \& Shannak, R. (2012). Intermediary Effects of Knowledge Management Strategy and Learning Orientation on Strategic Alignment and Firm Performance. Research Journal of International Studies, 112-128.

Masa'deh, R., Gharaibeh, A., Tarhini, A., \& Obeidat, O. (2015a). Knowledge Sharing Capability: A Literature Review. In Fourth Scientific \& Research Conference on New Trends in Business, Management and Social Sciences, Istanbul, Turkey, 19-20 September 2015 (pp. 1-16). https://doi.org/10.2139/ssrn.2696924

Masa'deh, R., Obeidat, B., \& Al-Dmour, R. (2015b). Knowledge Management Strategies as Intermediary Variables between IT-Business Strategic Alignment and Firm Performance. European Scientific Journal, 11(7), 344-368.

Masa'deh, R., Obeidat, B., \& Tarhini, A. (2016). A Jordanian Empirical Study of the Associations among Transformational Leadership, Transactional Leadership, Knowledge Sharing, Job Performance, and Firm Performance: A Structural Equation Modelling Approach. Journal of Management Development, 35(5), 681-705. https://doi.org/10.1108/JMD-09-2015-0134

Masa'deh, R., Shannak, R., Maqableh, M., \& Tarhini, A. (2017). The Impact of Knowledge Management on Job Performance in Higher Education: The Case of the University of Jordan. Journal of Enterprise Information Management, 30(2), 244-262. https://doi.org/10.1108/JEIM-09-2015-0087

Nunkoo, R., \& Ramkissoon, H. (2011). Developing a Community Support Model for Tourism. Annals of Tourism Research, 38(3), 964-988. https://doi.org/10.1016/j.annals.2011.01.017

Nusair, K., \& Kandampully, J. (2008). The antecedents of customer satisfaction with online travel services: a conceptual model. European Business Review, 20(1), 4-19. https://doi.org/10.1108/09555340810843663

Nusair, K., Parsa, H. G., \& Cobanoglu, C. (2011). Building a model of commitment for Generation Y: An empirical study on e-travel retailers. Tourism Management, 32(4), 833-843. https://doi.org/10.1016/j.tourman.2010.07.008

Nassar, B., \& Arzoky, M. (2015). An Empirical Analysis of the Seasonal Patterns in Aggregate Directors' Trades. International Journal of Economics and Finance, 7(9), 59-84. https://doi.org/10.5539/ijef.v7n9p59

Obeidat, B. Y., Hashem, L., Alansari, I, \& Al-Salti, Z. (2016). The Effect of Knowledge Management Uses on Total Quality Management Practices: A Theoretical Perspective. Journal of Management and Strategy, 7(4), 18-29. https://doi.org/10.5430/jms.v7n4p18

Obeidat, B., Al-Suradi, M., \& Tarhini, A. (2016). The Impact of Knowledge Management on Innovation: An Empirical Study on Jordanian Consultancy Firms. Management Research Review, 39(10), 1214-1238. https://doi.org/10.1108/MRR-09-2015-0214

Obeidat, B., El-Rimawi, S., Maqableh, M., \& Al-Jarrah, I. (2013). Evaluating the Profitability of the Islamic Banks 
in Jordan. European Journal of Economics, Finance and Administrative Sciences, 56, 27-36.

Obeidat, B., Sweis, R., Zyod, D., \& Alshurideh, M. (2012). The Effect of Perceived Service Quality on Customer Loyalty in Internet Service Providers in Jordan. Journal of Management Research, 4(4), 224-242. https://doi.org/10.5296/jmr.v4i4.2130

Obeidat, B.Y., Al-Sarayrah, S., Al-Salti, Z., \& Sweis, R. (2016). Cultural Influence on Strategic Human Resource Management Practices: A Jordanian case study. International Business Research, 9(10), 94-114. https://doi.org/10.5539/ibr.v9n10p94

Obeidat, B.Y., Tarhini, A., \& Aqqad, N. (2017). The impact of intellectual capital on innovation via the mediating role of knowledge management: A structural equation modeling approach. International Journal of Knowledge Management Studies, 8(2), 15-33.

Orozco, J., Tarhini, A., Masa'deh, R., \& Tarhini, T. (2015). A framework of IS/business alignment management practices to improve the design of IT Governance architectures. International Journal of Business and Management, 10(4), 1-12. https://doi.org/10.5539/ijbm.v10n4p1

Pallant, J. (2005). SPSS Survival Manual: A Step Guide to Data Analysis Using SPSS for Windows Version 12. Chicago, Illinois: Open University Press.

Sekaran, U., \& Bougie, R. (2013). Research Methods for Business: A Skill-Building Approach (6th ed.). New York: Wiley.

Shannak, R., \& Akour, M. (2012). Knowledge Management Strategy Building: Literature Review. European Scientific Journal, 8(15), 143-168.

Shannak, R., Al-Zu'bi, Z., Alshurideh, M., \& Altamony, H. (2012a). A Theoretical Perspective on the Relationship between Knowledge Management Systems, Customer Knowledge Management, and Firm Competitive Advantage. European Journal of Social Sciences, 32(4), 520-532.

Shannak, R., Obeidat, B., \& Almajali, D. (2010). Information Technology Investments: A Literature Review. Proceedings of the 14th IBIMA Conference on Global Business Transformation through Innovation and Knowledge Management: An Academic Perspective, Istanbul-Turkey, 23rd-24th June, pp.1356-1368.

Shannak, R., Obeidat, B., \& Masa'deh, R. (2012b). Culture and the Implementation Process of Strategic Decisions in Jordan. Journal of Management Research, 4(4), 257-281. https://doi.org/10.5296/jmr.v4i4.2160

Tarhini, A., Al-Badi, A., Almajali, M., \& Alrabayaah, S. H. (2017). Factors influencing employees' Intention to use Cloud Computing. Journal of Management \& Strategy, 8(2), 47-62. https://doi.org/10.5430/jms.v8n2p47

Tarhini, A., Elyas, T., Akour, M. A., \& Al-Salti, Z. (2016). Technology, Demographic Characteristics and E-Learning Acceptance: A Conceptual Model Based on Extended Technology Acceptance Model. Higher Education Studies, 6(3), 72-89. https://doi.org/10.5539/hes.v6n3p72

Tarhini, A., El-Masri, M., Ali, M., \& Serrano, A. (2016). Extending the UTAUT model to understand the customers' acceptance and use of internet banking in Lebanon: A structural equation modeling approach. Information Technology and People, 29(4), 830-849. https://doi.org/10.1108/ITP-02-2014-0034

Tarhini, A., Arachchilage, N., \& Abbasi, M. (2015). A Critical Review of Theories and Models of Technology Adoption and Acceptance in Information System Research. International Journal of Technology Diffusion, 6(4), 58-77. https://doi.org/10.4018/IJTD.2015100104

Tarhini, A., Mgbemena, C., AbouTrab, M.S., \& Masa'deh, R. (2015). User Adoption of Online Banking in Nigeria: A Qualitative study. Journal of Internet Banking and Commerce, 20(3), 1-8.

Tarhini, A., Mohammed, A., \& Maqableh, M. (2016). Modeling Factors Affecting Student's Usage Behaviour of E-Learning Systems in Lebanon. International Journal of Business and Management, 11(2), 299. https://doi.org/10.5539/ijbm.v11n2p299

Vratskikh, I., Al-Lozi, M., \& Maqableh, M. (2016). The Impact of Emotional Intelligence on Job Performance via the Mediating Role of Job Satisfaction. International Journal of Business and Management, 69-91. https://doi.org/10.5539/ijbm.v11n2p69 